\title{
Evaluation Implementation Of Regional Program Empowering “Gotong Royong” In New Autonomy Region
}

\author{
Judhi Ichtiyar Abdulkadir ${ }^{1}$, R. Madhakomala ${ }^{2}$, Fahmi Idris ${ }^{3}$ \\ ${ }^{1}$ Doctoral Program, Human Resources Management, Jakarta State University, Indonesia \\ ${ }^{2,3}$ Lecturer, Jakarta State University, Indonesia
}

\begin{abstract}
This research aims to illustrate the success of a program. The Stufflebeam CIPP Evaluation Model with the view that the most important goal of evaluation is not proving but to improve. And has been the program of Regional Empowerment of "Gotong Royong" (Mutual Cooperation), is an empowerment program; and as a complex function of community management, governance involves relationships between the various forces within the State in the region of local government, civil society, economic society and political society. Empowerment that prioritizes the importance of participation of all societies, to participate actively from the planning stage to the stage of evaluation, and development (bottom-up planning). This mechanism of community empowerment aims to accelerate the prevention of society that bears the Predicate of Social Welfare Problems. Poverty and one of the principles of governance is the network. West Sumbawa Regency as a New Autonomous Region, thereby governance when the authority is decentralized to power centers of many people / groups / institutions, where one another controls (checks and balances) to then build collaboration and network of activities that support each other in an integrated design team (IDT). Some of the indicators used in this study are targeted beneficiaries, community participation, and benefits received by the community. Based on the observations in the field and data processing obtained that first; for beneficiary target indicators, the most beneficiaries of the PoSWP are the poor in the sector; Micro, Agriculture, Livestock, and Fishery \& Marine. Second; Indicator of community participation, obtained by category in medium participation. Third; for the benefit indicator received, it was found that the benefits of the skills, knowledge, health, and income received by the village community were categorized in the moderate rise category.
\end{abstract}

Keywords: CIPP Evaluation Model, Empowerment, Mutual Cooperation, Participation Program

\section{Introduction}

Bureaucracy reform is a momentum to make fundamental changes about; how to plan a program that is oriented towards the welfare of its people. Change is a necessity both because of the emergence of the influence of the internal itself as well as external influences. For example, in public services, the bureaucratic sector is more in a state of "asking to be served" rather than "giving service" to the community. With the change of paradigm in the body of bureaucracy, the necessity to make changes both on the structure and on the cultural aspects as external factors (environmental factors), but have a very big impact for the organization concerned.

Empowerment; As a complex community management function, governance involves relationships between various forces within the state, namely state, civil society, economic society and political society. And one of the principles of governance is network. Thus it is said that governance when the authority is decentralized to the many power centers, and not concentrated in one person / group / institution, one with the other control each other (check and balance). All components of society have access to empowerment that would be more or less comparable to then build a collaboration and network of activities that support each other for the creation of a new social order. 
Regional Program of Mutual Cooperation Empowerment which is reviewed by Management Science, especially Human Resource Management, Evaluation of Program Implementation, covering 4 (four) sub. The focus is;

1. Goals and objectives, the foundation of the Program and the need for empowerment for the community, in an effort to provide quality benefits (worth and merit) for people with PoSWP,

2. Strategy, Method, Program Plan, Development Structure, Budget and Fund Source, Facilities and Infrastructure and Recruitment of Agent of Change in the empowerment of the poor, persuasively and targeted, linked to Mutual Cooperation Principle,

3. Implementation as well as supporting and inhibiting factors in realizing special empowerment for the poor,

4. Empowerment in improving the competence and performance of Agent, in developing productive economic activities and its impact on improving people's welfare.

\section{Material / Methodology \\ Empowerment}

Goetsch, Seen; (2014; 121), often misunderstood as a concept. When organizations give autonomous (employee) people to make decisions based on established parameters, or give them a single vote in making key decisions, they not only try to create good employee feelings. Management is trying to improve the performance of the organization. Empowerment will increase morale in one organization and that's what matters, but much more important is that it will improve the performance of both individuals and teams, productivity, quality, and competitiveness,

Fetterman $(1996,2001)$ as the author of the book "empowerment evaluation" in Marvin C. Atkin, (2013: 45) describes that; as a process that encourages self-determination among recipients from program evaluation, often including "training, ease-of-use, defense, illumination and liberation". From the evaluation of empowerment, it is to foster the right of self-determination rather than dependence, to the destination where the participant program includes the client actually to control their own evaluation

The concept of mutual cooperation, explicitly also stated in Regional Regulation No. 3 of 2016, as follows; And mutual cooperationis a community cooperation activity, both individually and in groups in various fields of development. Referral to the strengthening of unity and unity as well as the active role of the community in the framework of improving the socio-economic welfare of the community and the development of the socio-economic region. Robert Bacal $(2012 ; 2)$ that there are three terms, often used interchangeably, to propose an annual meeting. Leaders and subordinates discuss employee performance especially here Agent of Change, document progress (success and problems), and apply problem-solving approaches to solve current and future problems.

Evaluations, Measurements and Assessments show clearly that these three concepts of the previous two concepts have distinctions that are often strung together in a purposeful activity.

However, Robert Bacal (2012: 3) warned to be careful in using the term, because "Performance Appraisal is not Performance Management". Do not make the mistake of thingking that evaluating or appraising performance is the same as managing performance. It's not. Evaluating performance is but a part of a performance management system. If you only evaluate performance and do not do the other parts, you 'll fall. Meanwhile Scriven, in Jody L. Fitzpatrick, Christina Christie, Melvin M. Mark $(2009 ; 1)$ explains that the traditional definition of evaluation involving the examination of "value" and "quality" over something is for example; programs, policies and or products believed to be true to the existence of such Value and Quality. (Scriven 1967. 1991). David L Goetsch, Stanley Davis Seen (2012: 119) that motivation feels strong ownership-employees who are physically, intellectually, and emotionally engaged in workmanagement. The necessity of creating openness, not feeling threatened, because a creative and open environment will in turn encourage employee engagement; expect employees to think; recognize the value of employees; and in return for employee ownership of processes, production, and services. The context of HR management, the interaction of the Reform Agent with the harmonious, participatory and loyal government and community will certainly only be created if formal and informal communication can be done well.

Model of Financial Management Empowerment 
David Jeffee (2001: 116) that "There should be a rule" is true to say "there are also some meanings around here." The provisions do many things within the organization, they protect as well as the boundaries; coordinate as well as blocking; channeling efforts also limit this ... Social Scientists, no less like people on the streets, sadly accuse them, in organizations that are used without rules. But organizations without rules and conditions that may come from any thoroughly automatic ... or completed professionally ... are just one small fraction of the organization that matches any case. However, the controls performed on the financial aspects of the effective and efficient principles must be realized.

Bureaucratic oversight requires great and serious attention, in its use, workers are immune to the oversight of the formal structure and social relations of bureaucratic organizations. As described by Edward (1979: 21) in David Jeffee (2001: 116) Feature description with bureaucratic control is institutionalization with the hierarchical power of "Legal Certainty" The terms of the firm place "provisions on the basis of supervisory orders" on the direction of work, the procedure for evaluating the performance of its workers , and experimental and reward sanctions; supervisors and workers become subject to dictation of "company policy." Jobs are divided at very high levels; each job is given a different title from the description; and the provisions are not individual ones taking care of the promotion. "Loyal to the cooperation" is what the worker says, "and you will be able to climb the ladder" because the company also promises workers for a career.

Armstrong $(2009 ; 146)$ that; The budget is a planning and control tool, thereby allowing anticipation to make adjustments, so that it can then be used as guidelines and benchmarks that will be very useful for the management of government as an effort to avoid a biased understanding of the budget. Ronald Tebb's explanation, edited by Stanley Cliver, $(1975,24)$, he explained that a number of weaknesses in budgetary oversight, is due to the wide flow in this division. So as a quantitative planning of a certain amount of funds should be within certain limits as well. Stanley $(1975,139)$ Empowerment and quality improvement Agent of Change with a reliable HR management system aims to:

a. Improve and develop the knowledge, abilities and skills of the Agents of Change. In building managerial capabilities in all lines of a strong, professional and responsible.

b. Establish the attitude and behavior of the Agent of Change in accordance with the proper position, ie the trustee entrusted to him / her to run well and give accountability for the stipulated time.

c. Creating the same mindset or perception in understanding and applying management patterns, both in terms of laws and regulations as well as technical managerial implementation so much easier in conducting supervision.

\section{Implementation}

This research is based on a desire to describe how the Regional Program of Mutual Cooperation Empowerment (RPMCE) can provide solutions to create prosperity for the poor. While the social empowerment program in West Sumbawa has been obstructed, in addition to its 184,902 ha of land area, with the total population in 2009 recorded 101,089 inhabitants. It consists of 8 Sub-Districts and 58 Villages. Based on data of December 2015, the poverty rate of West Sumbawa Regency is $16.45 \%$ from 132,018 population. The number of PMKS (are poor communities of the term Social Welfare Problems), that must be addressed is 18,569 people more or about $14.06 \%$. The location is far apart with limited means of roads so it is very influential on the implementation of empowerment in the data collection of people with social problems in addition to the number of limited apparatus.

Outcomes of empowerment results on the quantitative data, indicating that the population data amounted to 135,031 inhabitants. Data input from Villages, Peliuk (an association of Agency nearby villages) and Sub-Districts ows that there are 63,217 people who have received Underdevelopment Support.

Citing statistical data on December 2015, that there are still $16.45 \%$ of the number of poor population of 132018 inhabitants. If the new handled new 3,148, means only $2.3 \%$ then there are still 18,569 people or $14.06 \%$ of the poor.

Even though there is an additional population of 3,013 people or $2.28 \%$ but the number of poor people drops significantly, there are only 4,483 people or $3.32 \%$ of the total population. However, if seen only from the decline in the poverty rate of the last 2 (two) years, ie (2016 and 2017), from 18,569 people to only 4,483 , means there is a decrease of 14,086 people or $75.88 \%$ or an average of $37.93 \%$ per year?

The concept of empowerment was born as an antithesis to the model of development and a model of industrialization that was less favorable to the majority. Conducting activities according to detailed plan of 
operational procedures to implement the program, need a good cooperation between the Agent of Change and the community. Increasing community participation in the implementation of Program Evaluation activities. Determine the evaluation method and evaluate with the community.

As Elie Greisler points out in Elie Greisler and Nilmini Wickramasinghe, $(2009 ; 140)$ barriers exist in technological, organizational and human aspects. From a technological standpoint the barriers include the choice of the system (hardware and software), and it's not that easy to implement. This is a system that requires complex and costly creating procedures or requires the co-operation of too many pre-existing units or systems to the organization, making it difficult to gain distance and cross-enterprise acceptance and cooperation.

Implementation Mechanism of the Mutual Cooperation Regional Program

The mechanism is essentially an Greek word absorption word mechane which means an instrument, and mechos which means a method, a means and a technical function of running a function. So a mechanism can be interpreted as a view that describes the relationship and interaction of some parts that exist in a particular system. Meanwhile, a system consists of a network of procedures, while the procedure is a sequence of clerical activities, the order of administrative work (clerical work).

Speaking of mechanisms, there must be a common and uniform understanding of several elements in the program implementation, namely; What program (What), Why should it be implemented (Why), Where should the program be placed (Where), When the program is implemented (When) and Who is (Who) and who will be responsible for its implementation (Whose), and How and in what way should do it (How). All of them should have been formulated clearly, in an effort to avoid overlapping so as not to show multiple interpretations of the intentions contained and stipulated in the standard rules, with their bound and binding nature.

Writing of this research using qualitative approach, The approach used is descriptive analysis, Interview that has been done with Muspida (is an abbreviation of the Regional Leadership Deliberation. Muspida consists of Regent, Chief of Police, Military District Commander, Chief of State Affairs, and Chairman of District Court). This is called the Second Level Muspida. as part of Integrated Design Team, both direct and written. Assignment of the Agent of Change was also asked for his opinion through a separate instrument, which was associated with an indicator of the factors present in the CIPP model component.

Table 1. Evaluation Criteria and Local Government Implementation Program Implementation Mutual Cooperation

\begin{tabular}{|c|c|c|c|c|c|}
\hline $\begin{array}{c}\text { Evaluation } \\
\text { Stage }\end{array}$ & $\begin{array}{l}\text { Evaluation } \\
\text { Components }\end{array}$ & Aspects Evaluated & Criteria & Scale & Data source \\
\hline & $\begin{array}{l}\text { The goals, goals } \\
\text { and benefits of } \\
\text { the Agent of } \\
\text { Change }\end{array}$ & $\begin{array}{l}\text { 1. The purpose of } \\
\text { empowerment is } \\
\text { in accordance } \\
\text { with the problems } \\
\text { encountered in } \\
\text { the development } \\
\text { of people's } \\
\text { cycles. } \\
\text { 2. The target of } \\
\text { empowerment in } \\
\text { accordance with } \\
\text { the dynamics of } \\
\text { development in } \\
\text { the community } \\
\text { 3. Benefits of } \\
\text { empowerment in } \\
\text { accordance with } \\
\text { the expectations } \\
\text { of the Regional } \\
\text { Government. }\end{array}$ & $\begin{array}{l}\text { 1. Achievement } \\
\text { goals } \\
\text { 2. The target } \\
\text { accuracy } \\
\text { 3. Compatibility }\end{array}$ & $\begin{array}{l}\text { 1. Done } \\
\text { 2. Enough } \\
\text { 3. Done }\end{array}$ & $\begin{array}{l}\text { 1. Regent's } \\
\text { Regulation } \\
\text { concerning; } \\
\text { RPoMCE } \\
\text { 2. Guidelines for the } \\
\text { management and } \\
\text { development of } \\
\text { community } \\
\text { empowerment; } \\
\text { 3. Interviews; with } \\
\text { implementers and } \\
\text { target groups; } \\
\text { 4. Observation } \\
\text { Results }\end{array}$ \\
\hline
\end{tabular}




\begin{tabular}{|c|c|c|c|c|c|}
\hline \multirow[t]{2}{*}{ Context } & $\begin{array}{l}\text { Platform Agent } \\
\text { of Change }\end{array}$ & $\begin{array}{l}\text { 1. The clarity of the } \\
\text { legal basis } \\
\text { underlying the } \\
\text { implementation } \\
\text { of the Agent of } \\
\text { Change } \\
\text { 2. Consistency of } \\
\text { rules as guidance } \\
\text { in the } \\
\text { implementation } \\
\text { of the Agent of } \\
\text { Change }\end{array}$ & 2. Consistence & 2. Enough & $\begin{array}{l}\text { 1. Regent regulation } \\
\text { concerning; } \\
\text { RPoMCE } \\
\text { 2. Guidelines for } \\
\text { themanagement } \\
\text { and development } \\
\text { of community } \\
\text { empowerment; } \\
\text { 3. Interviews; with } \\
\text { implementers, } \\
\text { subjects and target } \\
\text { groups } \\
\text { 4. Observation } \\
\text { Results }\end{array}$ \\
\hline & $\begin{array}{l}\text { NeedsRenewal } \\
\text { Agent }\end{array}$ & $\begin{array}{l}\text { 1. Need of } \\
\text { empowerment } \\
\text { Agent in } \\
\text { overcoming } \\
\text { problem } \\
\text { management of } \\
\text { target group. } \\
\text { 2. Needs Agent } \\
\text { empowerment in } \\
\text { overcoming the } \\
\text { problem of } \\
\text { productive } \\
\text { economic } \\
\text { development. }\end{array}$ & 2. Fulfilled & 2. Less & $\begin{array}{l}\text { 1. Regulation of } \\
\text { Regent about; } \\
\text { RPoMCE } \\
\text { 2. Guidelines for the } \\
\text { management and } \\
\text { development of } \\
\text { community } \\
\text { empowerment; } \\
\text { 3. Interviews;with } \\
\text { implementers and } \\
\text { target groups } \\
\text { 4. Observation } \\
\text { Results }\end{array}$ \\
\hline \multirow[b]{3}{*}{ Input } & $\begin{array}{l}\text { Agent's strategy } \\
\text { and method of } \\
\text { empowerment }\end{array}$ & $\begin{array}{l}\text { 1. Strategy to } \\
\text { enhance the role, } \\
\text { capability, and } \\
\text { potential of the } \\
\text { Agent of Change. } \\
\text { 2. Methods to } \\
\text { enhance the role, } \\
\text { capability and } \\
\text { potential of the } \\
\text { Agent ohange, }\end{array}$ & 2. Appropriateness & 2.Enough & $\begin{array}{l}\text { 1. Regents } \\
\text { regulations on } \\
\text { RPoMCE } \\
\text { 2. Guidelines for the } \\
\text { management and } \\
\text { development of } \\
\text { community } \\
\text { empowerment; } \\
\text { 3. Interviews with } \\
\text { executing elements } \\
\text { and target groups } \\
\text { 4. Observation } \\
\end{array}$ \\
\hline & $\begin{array}{l}\text { Agent } \\
\text { Empowerment } \\
\text { Planning }\end{array}$ & $\begin{array}{l}\text { 1. Planning to } \\
\text { improve the role } \\
\text { of Agent Renewal } \\
\text { 2. Planning to } \\
\text { improve the } \\
\text { ability of Agent } \\
\text { Renewal } \\
\text { 3. Planning to } \\
\text { increase the } \\
\text { potential Agent } \\
\text { of. Change }\end{array}$ & $\begin{array}{l}\text { 1. Consistence } \\
\text { 2. Relevance }\end{array}$ & $\begin{array}{l}\text { 1. Done } \\
\text { 2. Enough } \\
\text { 3. Not yet }\end{array}$ & $\begin{array}{l}\text { 1. Guidelines for } \\
\text { managing and } \\
\text { developing } \\
\text { community } \\
\text { empowerment; } \\
\text { 2. Interviews with } \\
\text { implementers and } \\
\text { target groups; } \\
\text { 3. Observation } \\
\text { Results }\end{array}$ \\
\hline & $\begin{array}{l}\text { Agent } \\
\text { empowerment } \\
\text { program }\end{array}$ & $\begin{array}{l}\text { 1. Program to } \\
\text { enhance the role } \\
\text { of Agent Change. } \\
\text { 2. Program to } \\
\text { upgrade Agent of } \\
\text { Change } \\
\text { 3. Program to } \\
\text { increase the } \\
\text { potential of } \\
\text { Updates Agent of } \\
\text { Change. }\end{array}$ & $\begin{array}{l}\text { 1. Consistence } \\
\text { 2. Relevance } \\
\text { 3. Appropriateness }\end{array}$ & $\begin{array}{l}\text { 2. Enough } \\
\text { 3. Enough }\end{array}$ & $\begin{array}{l}\text { 1. Guidelines for } \\
\text { themanagement } \\
\text { and development } \\
\text { of bailout } \\
\text { management; } \\
\text { 2. Interview of } \\
\text { interview with } \\
\text { executor; subjects } \\
\text { and target groups; } \\
\text { 3. Observation } \\
\text { Results }\end{array}$ \\
\hline
\end{tabular}




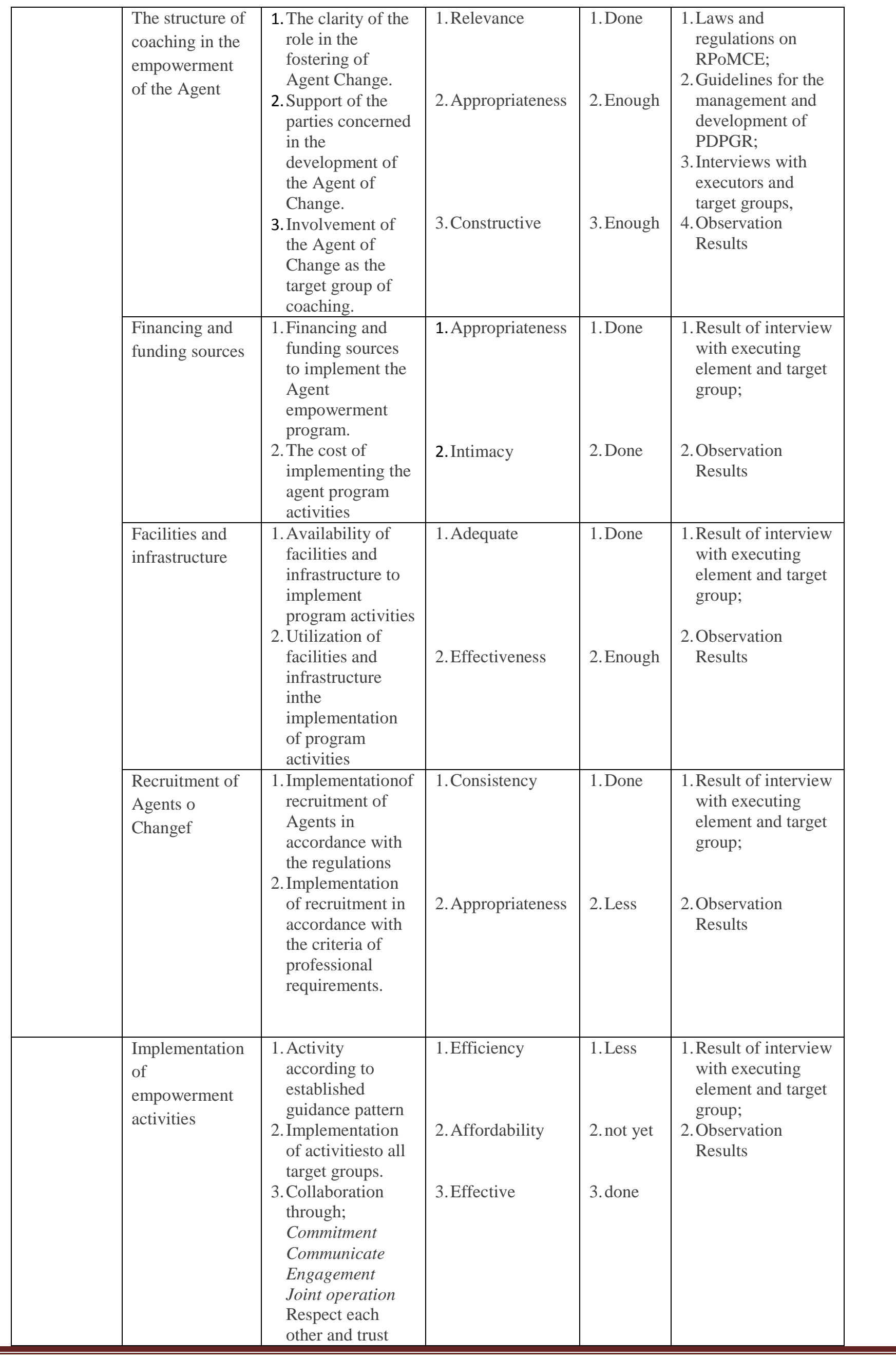




\begin{tabular}{|c|c|c|c|c|c|}
\hline \multirow[t]{3}{*}{ Process } & & $\begin{array}{l}\text { between the } \\
\text { Team }\end{array}$ & & & \\
\hline & Leadership & $\begin{array}{l}\text { 1. Confidence of } \\
\text { right information } \\
\text { from other } \\
\text { parties, } \\
\text { 2. The Team's } \\
\text { decisions reflect } \\
\text { all concerns } \\
\text { 3. Trust Team's } \\
\text { ability to each } \\
\text { other }\end{array}$ & $\begin{array}{l}\text { 1. Aligned } \\
\text { 2. Effective } \\
\text { 3. Effective }\end{array}$ & $\begin{array}{l}\text { 1. Done } \\
\text { 2.Done } \\
\text { 3. Enough }\end{array}$ & $\begin{array}{l}\text { 1. The laws and } \\
\text { regulations on } \\
\text { PDPGR; } \\
\text { 2. Guidelines for the } \\
\text { management and } \\
\text { development of } \\
\text { PDPGR; } \\
\text { 3. Interviews with } \\
\text { executors and } \\
\text { target groups, and } \\
\text { 4. Observation } \\
\text { Results }\end{array}$ \\
\hline & $\begin{array}{l}\text { Supporting and } \\
\text { inhibiting } \\
\text { factors }\end{array}$ & $\begin{array}{l}\text { 1. Supporting } \\
\text { factors are } \\
\text { utilized optimally } \\
\text { 2. The inhibiting } \\
\text { factor is handled } \\
\text { properly and } \\
\text { fundamentally. }\end{array}$ & $\begin{array}{l}\text { 1. Efficiency } \\
\text { 2. Accuracy and } \\
\text { solute }\end{array}$ & $\begin{array}{l}\text { 1.Done } \\
\text { 2.Less }\end{array}$ & $\begin{array}{l}\text { 1. Result of interview } \\
\text { with executing } \\
\text { element and target } \\
\text { group; } \\
\text { 2. Observation } \\
\text { Results }\end{array}$ \\
\hline \multirow[t]{3}{*}{ Product } & $\begin{array}{l}\text { Increased } \\
\text { competence and } \\
\text { performance of } \\
\text { Agent Renewal }\end{array}$ & $\begin{array}{l}\text { 1. Mindset about } \\
\text { management and } \\
\text { empowerment } \\
\text { development } \\
\text { 2.Improved } \\
\text { managerial and } \\
\text { strategic skills. } \\
\text { 3. Implementation } \\
\text { of competence in } \\
\text { the management } \\
\text { of Budgetting }\end{array}$ & $\begin{array}{l}\text { 1. Change } \\
\text { 2. Effectiveness } \\
\text { 3. Relevant }\end{array}$ & $\begin{array}{l}\text { 1. Done } \\
\text { 2.Less } \\
\text { 3. Not yet }\end{array}$ & $\begin{array}{l}\text { 1. Result of interview } \\
\text { with executing } \\
\text { element and target } \\
\text { group; } \\
\text { 2. Observation } \\
\text { Results }\end{array}$ \\
\hline & $\begin{array}{l}\text { Development of } \\
\text { productive } \\
\text { economic } \\
\text { empowerment }\end{array}$ & $\begin{array}{l}\text { 1. Benefits to the } \\
\text { development of } \\
\text { productive } \\
\text { economic } \\
\text { empowerment. } \\
\text { 2. Empowerment } \\
\text { that has } \\
\text { developed } \\
\text { productively }\end{array}$ & $\begin{array}{l}\text { 1. Effectiveness } \\
\text { 2. Enhancement }\end{array}$ & $\begin{array}{l}\text { 1. Done } \\
\text { 2.Less }\end{array}$ & $\begin{array}{l}\text { 1. Result of interview } \\
\text { with executing } \\
\text { element, subject } \\
\text { and target group; } \\
\text { 2. Observation } \\
\text { Results }\end{array}$ \\
\hline & $\begin{array}{l}\text { Impact on } \\
\text { improving } \\
\text { people's welfare }\end{array}$ & $\begin{array}{l}\text { 1. Utilization of } \\
\text { results for the } \\
\text { community in the } \\
\text { social field. } \\
\text { 2. The level of } \\
\text { empowerment for } \\
\text { the welfare of the } \\
\text { community }\end{array}$ & 2. Achievement & 2.Less & $\begin{array}{l}\text { 1. Result of interview } \\
\text { with executing } \\
\text { element, subject } \\
\text { and target group; } \\
\text { 2. Observation } \\
\text { Results }\end{array}$ \\
\hline
\end{tabular}

\section{Result and Discussion}

Based on the description of criteria and achievements, the following will provide an explanation of several factors that determine the success of program implementation significantly. 
1. Context ; Empowerment Agent of Change

Evaluation of this context helps to plan decisions, determine needs to be achieved by the program, and formulate program objectives.

To explain the Context of the Empowerment of the Agent of Change, the typical questions asked as part of the evaluation of the context are: (1) How needs assessment is done, (2) What needs are identified in the relevant community and how they are perceived and so important to the relevant community, and (3) To what extent are the objectives, objectives and priorities of welfare improvement, responsive to the needs judged by the justice and the underlying problems of the need.

\subsection{Objectives, Targets and Benefits in Empowerment of Agencies.}

Based on the above description, the evaluation of the objectives, objectives and benefits components in the context of the empowerment of Agencies in West Sumbawa Regency is shown in the Table 2. as follows

Table 2. Evaluation Results Components, Objectives, Targets and Benefits in Empowerment of Agencies.

\begin{tabular}{|c|c|c|}
\hline Aspects Evaluated & Objective Conditions & Evaluation result \\
\hline $\begin{array}{l}\text { 1. Purpose of } \\
\text { empowerment }\end{array}$ & $\begin{array}{l}\text { The purpose of empowering the Agent: } \\
\text { Improving the role of the Agent which includes } \\
\text { the extension and clarity of the tasks, } \\
\text { responsibilities, authorities, and rights and } \\
\text { forms of appreciation received; } \\
\text { 1. Increased competence and professionalism } \\
\text { including; mastery of knowledge, skills and } \\
\text { attitudes in accordance with the criteria of } \\
\text { professionalism; } \\
\text { 2. Increase the potential of Agent which } \\
\text { includes; developing the capacity of } \\
\text { individuals and groups in the management } \\
\text { and development of Agent in a professional } \\
\text { \& productive, in realizing the } \\
\text { empowerment of the poor. }\end{array}$ & $\begin{array}{l}\text { Already meet the criteria. } \\
\text { The purpose of empowerment is } \\
\text { in accordance with the problems } \\
\text { faced in developing the Agent. }\end{array}$ \\
\hline $\begin{array}{l}\text { 2. Target of } \\
\text { empowerment }\end{array}$ & $\begin{array}{l}\text { The target of the Agent's empowerment is } \\
\text { how to encourage the growth of productive } \\
\text { enterprises managed by professional Renewal } \\
\text { Agencies. }\end{array}$ & $\begin{array}{l}\text { Simply Meets the criteria. } \\
\text { The target of the Agency's } \\
\text { empowerment is in accordance } \\
\text { with the dynamics and } \\
\text { development of economic } \\
\text { activities in the community. }\end{array}$ \\
\hline $\begin{array}{l}\text { 3. Benefits of } \\
\text { empowerment }\end{array}$ & $\begin{array}{l}\text { The Benefits of Agent Empowerment is the } \\
\text { productivity of the Agent so that the results } \\
\text { can make a real contribution to the } \\
\text { continuous improvement of social welfare of } \\
\text { society from the social and economic } \\
\text { aspects. }\end{array}$ & $\begin{array}{l}\text { Simply Meets the criteria. } \\
\text { Benefits of empowerment of } \\
\text { Renewal Agent in accordance } \\
\text { with the expectations of } \\
\text { stakeholders. }\end{array}$ \\
\hline
\end{tabular}

From the evaluation results shown in the table above shows that the objectives, targets and benefits of the Agency's empowerment already meet the criteria set. Agent Empowerment has the right goal dimension, strong relevance to the problems encountered in program development. The facts show that the roles, competencies and professionalism, and potential of the Agencies are still low, but show the quality of work to be proud of.

\subsection{Evaluation of Legal / Policy and Consistency and Considerations in the Agent Empowerment Program}

Law of the Republic of Indonesia Number 32 Year 2004 regarding Regional Government; consideration of the letters (a) and article 14 paragraph (2) has set the existence and role of empowerment in development, clearly and very detailed. 
Based on the above description, it can be stated that the Evaluation Result of the Legal Platform / Policy Components in the Agent of Change Empowerment Program can be shown in the Table 3. as follows:

Table 3. Results of Component Evaluation of Legal / Policy and Consistency and Considerations in the Agent Empowerment Program

\begin{tabular}{|c|c|c|}
\hline Aspects Evaluated & Objective Conditions & Evaluation result \\
\hline 1. Legal Basis / Policy & $\begin{array}{l}\text { Legal / Policy Platform contains a definition } \\
\text { of clarity which is used as Guidance in the } \\
\text { effort of procurement and placement of Agent } \\
\text { of Change in community empowerment; } \\
\text { 1. Law of the Republic of Indonesia No. } 32 \\
\text { of } 2004 \text { on Regional Autonomy } \\
\text { 2. Law of Village, Transmigration and } \\
\text { Disadvantaged Areas Article } 83 \text { of Village } \\
\text { Law Number. } 6 \text { Year } 2014 \text { Community } \\
\text { Empowerment; } \\
\text { poweringblogspot.co.id/2014 consultant- } \\
\text { 3est Sumbawa Regent; REGIONAL } \\
\text { REGULATION NUMBER } 8 \text { of 2016 } \\
\text { concerning; Medium Term Plan (RPJMD) } \\
\text { Year 2016-2021. }\end{array}$ & $\begin{array}{l}\text { Meet the criteria. } \\
\text { The implementation of } \\
\text { community empowerment is } \\
\text { guided by consistent } \\
\text { regulations. }\end{array}$ \\
\hline $\begin{array}{l}\text { 2. Consistency and } \\
\text { Consideration Program. }\end{array}$ & $\begin{array}{l}\text { To further elaborate the program, the } \\
\text { requirement should be sustained by local } \\
\text { regulations, which are consistent in their } \\
\text { implementation based on; } \\
\text { a. Regent's West } \\
\text { REGULATION OF } \text { REGIONAL } \\
\text { NUMBER } 3 \text { of } 2016 \text { concerning; } \\
\text { Regional Program of mutual cooperation } \\
\text { Empowerment (PDPGR). } \\
\text { b. Regent's West Sumbawa; REGIONAL } \\
\text { REGULATION NUMBER } 8 \text { of 2016 } \\
\text { concerning; Medium Term Plan } \\
\text { (RPJMD) Year 2016-2021. } \\
\text { Regent's West } \\
\text { REGULATION OF REGIONAL } \\
\text { NUMBER 19 of } 2016 \text { concerning; The } \\
\text { PDPGR Guidelines for Planning, May } \\
\text { 30, 2016. }\end{array}$ & $\begin{array}{l}\text { Simply Meets the criteria. } \\
\text { Implementing the } \\
\text { empowerment of the } \\
\text { Renewal Agent in its tasks } \\
\text { and efforts to empower } \\
\text { communities by guiding } \\
\text { consistent regulations. }\end{array}$ \\
\hline
\end{tabular}

In the Table 3. it is shown that the empowerment of the poor by the Agent of Change is an implementation of the mandate of Law no. 32 of 2004 on Regional Autonomy. While the elaboration and implementation rule refers to the Regional Regulation as a detailed and consistent guideline in its implementation consistently.

\subsection{Empowerment Needs}

The Agent of Change is the party most responsible for the RPoMCE pardon entrusted to him. The responsibilities are shown in terms of managing the program, how to facilitate, mobilize, organize and control and develop specific tips in empowering the target group / poor community. 
Table 4. Evaluation of Components Needs of Agencies with Target Groups and Community Productive Economic Development in West Sumbawa Regency

\begin{tabular}{|c|c|c|}
\hline Aspects Evaluated & Objective Conditions & Evaluation result \\
\hline $\begin{array}{l}\text { 1. Needs of Renewal Agent } \\
\text { and Target Group }\end{array}$ & $\begin{array}{l}\text { How the ways and tips of the Agent of Change } \\
\text { managing the Target Group are, of course, } \\
\text { guided by the relevant Regional Device Work } \\
\text { Unit (RDWU), relevant and with reference to } \\
\text { existing rules; } \\
\text { 1. Provides an overview of the initial conditions } \\
\text { of the Target Group, } \\
\text { 2. Trying to be conditioned by the practice of } \\
\text { rotating (role play) of the Renewal Agent, } \\
\text { 3. Applying the principle of two-way } \\
\text { communication with emphasis on the } \\
\text { expected solution. }\end{array}$ & $\begin{array}{l}\text { Meet the criteria. } \\
\text { The implementation of the } \\
\text { Agent of Change in the } \\
\text { Management of the Target } \\
\text { Group should be with a } \\
\text { good and relevant approach } \\
\text { and communication } \\
\text { capability. }\end{array}$ \\
\hline $\begin{array}{l}\text { 2. Agent Needs and } \\
\text { Productive Economic } \\
\text { Development. }\end{array}$ & $\begin{array}{l}\text { How the tips and tips of the Update Agent in } \\
\text { explaining; what is the Productive Economic } \\
\text { Activity and how to actualize in the life of the } \\
\text { poor. Target and guidance in accompaniment by } \\
\text { related RDWU, while still referring to the } \\
\text { existing rules; } \\
\text { a. Explain what Economic Activity Produces } \\
\text { and its benefits. } \\
\text { b. Agent of Change be able to provide an } \\
\text { overview of what activities are included in } \\
\text { the Productive Economic Activity. } \\
\text { c. Agent of Change shall also be able to show } \\
\text { that with Productive Economic Activity } \\
\text { may increase the Prosperity of the Poor }\end{array}$ & $\begin{array}{l}\text { Meet the criteria. } \\
\text { Implementing the } \\
\text { empowerment of the Agent } \\
\text { of hange in the task and } \\
\text { effort of empowering the } \\
\text { community not only with } \\
\text { the provision of } \\
\text { communication but also } \\
\text { can actualize and be } \\
\text { absorbed by the Target } \\
\text { Group. }\end{array}$ \\
\hline
\end{tabular}

The basic understanding by any Agent of Change, concerning Productive Economic Activity is not merely communicated well, but how to actualize within the reach of the mindset of the poor. A number of tips can be developed through assistance by related RDWU, but the exchange of information between the Team can eliminate understanding gaps among the Team. Some illustrations that can quantitatively provide an understanding of the change of numbers let how the Productive Economic Activity is the upcoming changes in people's lives towards a more prosperous.

\section{Input Agent Empowerment}

The evaluation aims to help manage decisions, determine sources, alternatives to be taken, what plans and strategies needs to achieve, and how work procedures can be achieved.

\subsection{Strategy Components and Methods of Empowerment of Agencies}

Thus it becomes first and foremost how to explain what strategy and how the series of activities in programming. An action plan becomes an implementation activity that can give individual confidence that the strategies and activities will and have been implemented that explicitly refer to the needs and objectives of the program.

Based on the description on the components of strategies and methods in the process of empowering the Agent of Discovery are shown in the following Table 5.

Table 5. Evaluation Results of Strategy Components and Methods in Empowerment of Agencies in West Sumbawa Regency

\begin{tabular}{|c|c|c|}
\hline $\begin{array}{c}\text { Aspect } \\
\text { Evaluated }\end{array}$ & Objective Conditions & Evaluation Results \\
\hline
\end{tabular}




\begin{tabular}{|c|c|c|}
\hline $\begin{array}{l}\text { 1. Strategy to enhance the } \\
\text { role, capability, and } \\
\text { potential of } \\
\text { Empowerment } \\
\text { Agencies.. }\end{array}$ & $\begin{array}{l}\text { Empowerment Strategy of Agent of Change: } \\
\text { optimizing roles, } \\
\text { o Professionalization, } \\
\text { - Capacity building. }\end{array}$ & $\begin{array}{l}\text { Already meet the criteria. } \\
\text { The strategies used are } \\
\text { appropriate to enhance the } \\
\text { role, competence, and potential } \\
\text { of the Agent of Change. }\end{array}$ \\
\hline $\begin{array}{l}\text { 2. Methods to enhance } \\
\text { the role, capability and } \\
\text { potential of the Agent of } \\
\text { Change. }\end{array}$ & $\begin{array}{l}\text { Method of empowerment of the Agent of } \\
\text { Change } \\
\text { Optimizing roles through wider } \\
\text { assignment, responsibility, authority, rights } \\
\text { and rewards to encourage initiatives in } \\
\text { productive development. } \\
\text { Professionalization to improve the } \\
\text { competence and professionalism of the } \\
\text { Empowerment Agent through the delivery } \\
\text { of education and training. } \\
\text { Strengthening the capacity to increase the } \\
\text { potential of the Agent of Change in } \\
\text { productive development through the } \\
\text { formation and fostering of the first-rate } \\
\text { Agencies / Agencies as the Peliuk } \\
\text { (association of Agent), }\end{array}$ & $\begin{array}{l}\text { Sufficient to meet the criteria } \\
\text { The methods used are } \\
\text { appropriate to enhance the } \\
\text { role, competence, and } \\
\text { potential of the Agent of } \\
\text { Change. }\end{array}$ \\
\hline
\end{tabular}

The results of the evaluation indicate that the strategies used in the Empowerment of the Agent of Change have met the criteria. There are three main strategies that are used: (1) optimizing roles to increase roles, (2) professionalization to improve capability, and (3) strengthening capacity to increase potential, not yet overall can be realized.

\subsection{Evaluation Results of Planning Components in Empowerment of Agencies}

The stages of the Renewal Agent empowerment process defined in the planning involves the following activities: (1) arrangement of the role of the Renewal Agent in the form of rules and guidelines on duties, responsibilities, authorities, obligations, rights and rewards in the management and development of program activities; (2) the implementation of education / training (Training) to improve the capability / competence of the Agent o Changef in performing the duties; and (3) the establishment and coaching of the Association / Forum Agent Renewal Group is called a Peliuk Agent.

Based on the above description, the following evaluation results can be presented :

Table 6. Evaluation Results of Planning Components in Empowerment of Agencies

\begin{tabular}{|c|c|c|}
\hline $\begin{array}{c}\text { Aspect } \\
\text { Evaluated }\end{array}$ & Objective Condition & Evaluation Result \\
\hline $\begin{array}{l}\text { 1.Planning to improve } \\
\text { the role of Agent of } \\
\text { Change }\end{array}$ & $\begin{array}{l}\text { - Planning to improve the role of the Agent of } \\
\text { Change is determined in accordance with } \\
\text { the strategies and methods used. } \\
\text { Arrangement of roles in the form of } \\
\text { regulations in the form of guidelines, duties } \\
\text { and responsibilities, authority, obligations } \\
\text { and rights and rewards for its role, }\end{array}$ & $\begin{array}{l}\text { Already meet the criteria } \\
\text { Planning to enhance roles is } \\
\text { tailored to the strategies and } \\
\text { methods set }\end{array}$ \\
\hline $\begin{array}{l}\text { 2. Planning to improve } \\
\text { the ability of the } \\
\text { Agent of Change }\end{array}$ & $\begin{array}{l}\text { - Planning to improve the ability of the Agent } \\
\text { of Change is designed in accordance with } \\
\text { the pre-determined planning. namely the } \\
\text { implementation of education and training to } \\
\text { improve the ability and competence }\end{array}$ & $\begin{array}{l}\text { Self Meets the criteria } \\
\text { Planning to improve skills } \\
\text { is done through appropriate } \\
\text { and pre-defined education } \\
\text { and training }\end{array}$ \\
\hline $\begin{array}{l}\text { 3. Planning to increase } \\
\text { the potential of the } \\
\text { Agent of Change }\end{array}$ & $\begin{array}{l}\text { - Planning to increase the potential of the } \\
\text { Agent of Change to be tailored to the } \\
\text { established plan of forming and fostering } \\
\text { the Reform Agent through the group, the } \\
\text { Association / Forum, is expected to increase }\end{array}$ & $\begin{array}{l}\text { Already meet criteria } \\
\text { Planning to increase } \\
\text { potential through Group } \\
\text { formation, Association / }\end{array}$ \\
\hline
\end{tabular}




\begin{tabular}{|l|l|l|}
\hline & $\begin{array}{l}\text { the potential and communication to establish } \\
\text { cooperation for the development of } \\
\text { activities in a fundamental and productive } \\
\text { way, }\end{array}$ & $\begin{array}{l}\text { pommication forum and } \\
\text { productive cooperation }\end{array}$ \\
\hline
\end{tabular}

The evaluation results show that the Agent of Change empowerment planning component has been established in accordance with the strategy and the method used. The stages of the Agent of Change empowerment process defined in the plan include: (1) arrangement of the role of the Agent of Change in the form of regulation and job description, responsibilities, authority, obligations, rights and rewards of the Agent of Change in the management and development of the program; (2) the implementation of education / training to improve the capability / competence of the Agent of Change in carrying out its duties and functions; and (3) initiation of formation and coaching through the Association / Forum Agent of Change group, and has been realized under the name of Peliuk Agent. Means made a concrete step, not only to increase the potential of Agencies, but in establishing interactive communication that will realize cooperation in the management of activities and productive development.

\subsection{Facilities and infrastructure}

As the process of change can not happen in a short time, therefore the focus of change should be directed to start on things that are very likely to be done gradually. And one of the evaluation of facilities and infrastructure is focused to assess the support of facilities and infrastructure required in the implementation of Agencies empowerment activities. Based on the above description, the following evaluation results can be presented at Table 7 .

Table 7. Evaluation Result of Infrastructure Means of Funds in Empowerment of Agencies in West Sumbawa Regency

\begin{tabular}{|c|c|c|}
\hline \multicolumn{1}{|c|}{$\begin{array}{c}\text { Aspects } \\
\text { Evaluated }\end{array}$} & \multicolumn{1}{c|}{ Objective Condition } & \multicolumn{1}{c|}{ Evaluation Result } \\
\hline $\begin{array}{l}\text { 1 Availability of facilities } \\
\text { and infrastructure to } \\
\text { carry out program } \\
\text { activities }\end{array}$ & $\begin{array}{l}\text { Available facilities and infrastructure } \\
\text { owned by the local government, for the } \\
\text { empowerment of Renewal Agencies, } \\
\text { including facilities for the organization } \\
\text { of training, workshops, and socialization } \\
\text { and communication media. }\end{array}$ & $\begin{array}{l}\text { Meet the criteria } \\
\text { Empowerment is } \\
\text { supported by adequate } \\
\text { facilities and infrastructure } \\
\text { owned by LGs }\end{array}$ \\
\hline $\begin{array}{l}\text { 2.Utilization of facilities } \\
\text { and infrastructure in the } \\
\text { implementation of the } \\
\text { program activities }\end{array}$ & $\begin{array}{l}\text { Facilities and infrastructure existing and } \\
\text { owned can be utilized to support } \\
\text { activities in the Empowerment Agent of } \\
\text { Change. }\end{array}$ & $\begin{array}{l}\text { Meet the criteria } \\
\text { Facilities and } \\
\text { infrastructure are utilized } \\
\text { for the implementation } \\
\text { Agent of Change } \\
\text { empowerment activities }\end{array}$ \\
\hline
\end{tabular}

The results of the evaluation shown above indicate that existing facilities and infrastructure needed to support the Renewal Agent empowerment activities are sufficient. Facilities and infrastructure include facilities for the organization of training, workshops, and media communication and socialization. These facilities and infrastructure belong to the Regional Government that can be utilized to support the Renewal Agent empowerment activities.

\section{Process ; Empowerment Agent of Change}

As Stufflebeam (1984) points out that First; "process evaluation, to serve the implementation decision" Second; the process of evaluation activity aims to assist the execution of the decision. Third; Worthy and Sanders (1990) explains that, the evaluation process has the purpose of: (1) detecting or predicting in procedural design or implementation during the implementation phase, (2) providing information for programmed decisions, and (3) to maintain records of the Procedure taken ".

\subsection{Implementation of Empowerment Activities}

Evaluation of the implementation of activities focused on assessing the implementation of activities in accordance with established guidance patterns. 
This can be seen based on the intensity of activities and the range or objectives of activities that have been implemented in order to empower the Agent of Change. Carry out activities in accordance with detailed plans of operational procedures to implement the program. It needs good cooperation between the Agent of Change and the community.

Table 8. Evaluation Results of the Implementation of Activity in Community Empowerment in West Sumbawa Regency

\begin{tabular}{|c|c|c|}
\hline $\begin{array}{r}\text { Aspect } \\
\text { Evaluated }\end{array}$ & Objective Conditions & Evaluation Results \\
\hline $\begin{array}{l}1 \text { Empowerment } \\
\text { activities carried } \\
\text { out according to the } \\
\text { guidance pattern }\end{array}$ & $\begin{array}{l}\text { Optimizing the role of the Agent of Change is } \\
\text { done through the arrangement of roles, } \\
\text { covering the duties, authorities, and } \\
\text { responsibilities in the form of rules and } \\
\text { guidelines on the role in the management and } \\
\text { development of community empowerment } \\
\text { programs especially for People with Poverty } \\
\text { and Social Problems (PoPSWP) } \\
\text { Implementation of socialization through } \\
\text { various media and orientation through } \\
\text { meetings to provide understanding to PMKS } \\
\text { about its task in managing and developing } \\
\text { empowerment program. } \\
\text { Professionalization of Renewal Agencies is } \\
\text { conducted through extension activities, } \\
\text { training, workshops, and technical guidance } \\
\text { Group coaching (Peliuk Agent) is carried out } \\
\text { on Associations / Forums in selected villages } \\
\text { and or sub-districts through meeting, } \\
\text { facilitation, consultations and advocacy if } \\
\text { necessary. }\end{array}$ & $\begin{array}{l}\text { Meet the criteria. } \\
\text { Empowerment activities } \\
\text { carried out according to the } \\
\text { pattern of coaching }\end{array}$ \\
\hline $\begin{array}{l}\text { 2.Implementation of } \\
\text { activities reaching } \\
\text { all target groups }\end{array}$ & $\begin{array}{l}\text { Intensity of activities has not reached all target } \\
\text { groups in remote villages in West Sumbawa } \\
\text { Regency }\end{array}$ & $\begin{array}{l}\text { Not fully meet the } \\
\text { criteria. } \\
\text { The intensity of the activity } \\
\text { has not fully reached all the } \\
\text { target groups that have been } \\
\text { inventoried before. }\end{array}$ \\
\hline $\begin{array}{l}\text { 3.Collaboration } \\
\text { through; }\end{array}$ & $\begin{array}{l}\text { Collaborative implementation of PoSWP } \\
\text { Empowerment activities done through concrete } \\
\text { actions in form; }\end{array}$ & It meets the criteria \\
\hline $\begin{array}{l}\text { Commitment } \\
\text { Communicate } \\
\text { Engagement } \\
\text { Joint operation }\end{array}$ & $\begin{array}{l}\text { Make constructive agreements in support } \\
\text { of task implementation, } \\
\text { Establish communication between teams so } \\
\text { avoid no mis communication that will } \\
\text { inhibit, }\end{array}$ & $\begin{array}{l}\text { The collaboration is fully } \\
\text { implemented, although the } \\
\text { intensity of the activity has } \\
\text { not fully reached all the } \\
\text { target groups that have }\end{array}$ \\
\hline $\begin{array}{l}\text { Respect each other } \\
\text { and trust between } \\
\text { the Team }\end{array}$ & $\begin{array}{l}\text { Self-involvement in every task execution } \\
\text { on the ground, if it stumbles from the target } \\
\text { group, } \\
\text { Joint operations are possible to deal with } \\
\text { the target group with rejection, } \\
\text { Mutual trust and respect between one Team } \\
\text { and another Team.. }\end{array}$ & been inventoried previously \\
\hline
\end{tabular}

Evaluation results indicate that the activities in the Empowerment Agent of Change in West Sumbawa Regency, has been implemented according to the planning and pattern of guidance set. Role optimization is done through the arrangement of tasks, authority, responsibilities of the Agent of Change, in the form of rules and guidelines on management in its development. The socialization of the guidelines and the various regulations became intent, to be properly understood. Professionalization is implemented through education in the form of guidance, counseling, training, and workshop activities. Group coaching is done through the formation of Association / Agent's Forum in each of the Villages (Peliuk's Agent), and through meetings and coaching, facilitation, consultation and advocacy initiated by the association. The activities of the association are directed to 
establish partnerships and / or cooperation with related parties with the development of Agent of Change and development towards professionalism.

Collaboration through Commitment, Communication, self-inclusion, joint operation and mutual respect and mutual trust, so that the implementation of Agent of Change activities is effective. It has not fully reached the target group as a whole, because geographically it still includes remote areas.

\subsection{Leadership in Community Empowerment}

Democratic leadership has made room for each team to obtain correct information from others. Thedecision taken by the Team is a common formula that reflects togetherness. Thereby demonstrating the trust in the Team's ability to interact with each other, to be effective and constructive.

In Human Resource management, a leader is a person who implements some things "people who do the right thing". While managers do something right "people who do things right". Managers who also act as organizers of the organizational management structure, clearly need rules and limitations as a reference and control in the implementation of tasks and roles. And therefore the person responsible for the quality of the human resources needs both completely, that is leadership and management skills especially related to change management.

Based on the results of interviews of several parties, provide the following description:

Table 9. Evaluation Results of Leadership Components in Community Empowerment Activities in West Sumbawa Regency

\begin{tabular}{|c|c|c|}
\hline $\begin{array}{c}\text { Aspect } \\
\text { Evaluated }\end{array}$ & Objective Condition & Evaluation Result \\
\hline $\begin{array}{l}1 \text { Confidence in the } \\
\text { correct information } \\
\text { of the other Team }\end{array}$ & $\begin{array}{l}\text { - Optimizing the role of the Agent of Change } \\
\text { is done through the arrangement of roles } \\
\text { covering the duties, authorities, and } \\
\text { responsibilities in the form of rules and } \\
\text { guidelines on roles in the management and } \\
\text { development of community empowerment } \\
\text { programs for People with Social Welfare } \\
\text { Problems (PoSWP) } \\
\text { - Implementation of socialization through } \\
\text { various media and orientation through } \\
\text { meetings to provide understanding to the } \\
\text { Agent of Change about his duty in } \\
\text { managing and developing Community } \\
\text { empowerment program, } \\
\text { - Professionalization of Agencies is } \\
\text { conducted through extension activities, } \\
\text { training, workshops, and technical } \\
\text { guidance. } \\
\text { - Group coaching (Peliuk Agent) is carried } \\
\text { out on the Association / Forum in selected } \\
\text { villages and or sub-districts through } \\
\text { meetings, facilitation, consultation and } \\
\text { advocacy if necessary. }\end{array}$ & $\begin{array}{l}\text { Meet the criteria. } \\
\text { Empowerment activities } \\
\text { implemented in accordance } \\
\text { with pattern of coaching }\end{array}$ \\
\hline $\begin{array}{l}\text { 2. The team's } \\
\text { decisions reflect all } \\
\text { concerns }\end{array}$ & $\begin{array}{l}\text { The intensity of the activity has not reached } \\
\text { all target groups in the remote village of West } \\
\text { Sumbawa Regency }\end{array}$ & $\begin{array}{l}\text { Has not fully met the criteria. } \\
\text { The intensity of the activity has } \\
\text { not fully reached all the target } \\
\text { groups that have been } \\
\text { inventoried before }\end{array}$ \\
\hline
\end{tabular}




\begin{tabular}{|c|c|c|}
\hline $\begin{array}{l}\text { 3. Belief in Team } \\
\text { ability between } \\
\text { each other }\end{array}$ & $\begin{array}{l}\text { Collaborative implementation of PMKS } \\
\text { Empowerment activities done through } \\
\text { concrete actions in form; } \\
\text { O Make constructive agreements in support of } \\
\text { task implementation, } \\
\text { O Establish communication between teams so } \\
\text { avoid mis communication that will inhibit, } \\
\text { O Self-involvement in every task execution } \\
\text { on the ground, if the stumbling block from } \\
\text { the target group, } \\
\text { O Joint operations are possible to deal with } \\
\text { the target group with rejection, } \\
\text { O Mutual trust and respect between one Team } \\
\text { and another Team. }\end{array}$ & $\begin{array}{l}\text { It meets the criteria. } \\
\text { The collaboration is fully } \\
\text { implemented, although the } \\
\text { intensity of the activity has not } \\
\text { fully reached all the target } \\
\text { groups that have been } \\
\text { inventoried previously }\end{array}$ \\
\hline
\end{tabular}

Democratic leadership has made room for each Team to obtain correct information from others. The decision taken by the Team is a common formula that reflects togetherness. Thereby demonstrating the trust in the Team's ability to interact with each other, to be effective and constructive. The involvement of the Muspida (Deliberation of Regional Leadership) as the Steering Committee in the organization, is hierarchically an integrated Design Team. Thus, governance as a decentralized authority in power centers as a collection of many people / groups / institutions, where one another controls (checks and balances) and then builds collaboration and networks of mutually supportive activities within an Integrated Design Team (IDT). At the District level, there is also the Muspika (District Leadership Meeting), and at the Village level, especially the TNI (Indonesian National Army) with Babinsa (the rank of NCO coach in village) and Police with Babinkantibmas (the rank of NCO Coaching and Security, Public Order). In addition to the inherent tasks, as well as the PDPGR Movement Team not only provide information directly, but also oversight of program implementation in the field.

Other factors of course there are factors that are supportive and on the other hand there is also a hamper. And these inhibiting factors are handled well and persuasively. The agent will play a better role as a good listener, in an effort to accommodate and formulate what the constraints and how should solutive therapy be given.

\subsection{Supporting and Inhibiting Factors}

Evaluation of supporting and inhibiting factors is focused on assessing potential as a contributing factor and obstacles that impede the implementation of the Target Group's empowerment activities. Based on the above description, can be presented The results of evaluation as follows:

Table 10. Evaluation of Supporting and Inhibiting Components in PoSWP Community Empowerment in West Sumbawa Regency

\begin{tabular}{|c|c|c|}
\hline $\begin{array}{l}\text { Aspect } \\
\text { Evaluated }\end{array}$ & Objective Condition & Evaluation Result \\
\hline $\begin{array}{l}\text { 1. Supporting factors are } \\
\text { utilized optimally }\end{array}$ & $\begin{array}{l}\text { - Supporting factors that are used } \\
\text { include partnerships among } \\
\text { government agencies, as a steering } \\
\text { institution, as well as regulations and } \\
\text { guidelines as a reference process of } \\
\text { direction and direct coaching to the } \\
\text { target group. } \\
\text { - Supporting factors optimally } \\
\text { utilized, among others, still not much } \\
\text { outside influence over the living } \\
\text { order of traditional societies, }\end{array}$ & $\begin{array}{l}\text { Already meet the criteria. } \\
\text { Situation and condition of } \\
\text { society life that have not got } \\
\text { outside influence become } \\
\text { supporting factor which is } \\
\text { utilized optimally }\end{array}$ \\
\hline
\end{tabular}




\begin{tabular}{|c|c|c|}
\hline $\begin{array}{l}2 \text { Inhibiting factors are handled } \\
\text { properly }\end{array}$ & $\begin{array}{l}\text { - Communicative barriers; interaction } \\
\text { with outsiders, traditional } \\
\text { community attitudes, customs and } \\
\text { addictions, became the Agent's } \\
\text { renewed weak point for direct } \\
\text { contact. } \\
\text { - Technical barriers; The development } \\
\text { of science and technology is slow, } \\
\text { superego, reluctant to make } \\
\text { changes, and do not want to follow } \\
\text { the pattern of planting fit } \\
\text { (Regression) in the agricultural } \\
\text { sector agricultural for example. Is a } \\
\text { problem in itself and can not be } \\
\text { handled optimally }\end{array}$ & $\begin{array}{l}\text { Not meet the criteria } \\
\text { There are still factors } \\
\text { obstacles that can not be } \\
\text { handled properly. }\end{array}$ \\
\hline
\end{tabular}

Other factors of course there are factors that are supportive and on the other hand there is also a hamper. And these inhibiting factors are handled well and persuasively. The agent will play a better role as a good listener, in an effort to accommodate and formulate what the constraints and how should solutive therapy be given.

\section{Product ; Empowerment Agent of Change}

Product evaluation is the assessment done to see the achievement / success of the empowerment program in achieving the set goals. At this evaluation stage evaluators can determine or make recommendations, whether a community empowerment program can be continued, expanded or modified, or even stopped entirely. At this stage of evaluation, questions are asked about the achievement of objectives, the relationship between the details of the process to achieve the objectives, the formulation that can be done, the requirements of the development program, and the impacts that can be derived from the existing empowerment program. In addition to this question, product evaluation also does the following: (1) measurement and interpretation of program development achievement, (2) looks at the main impact and adverse effects of the empowerment program; (3) see the advantages and compare with cost efficiency; (4) the determination of both absolute and relative criteria; and (5) the determination of success criteria in the short and long term.

\subsection{Evaluation of competence improvement and performance of Agency}

Evaluation of the improvement of competence and performance is focused on assessing the extent of success achieved through empowerment related to the professionalism of the Renewal Agencies.

Based on the above description, the following evaluation results can be presented:

Table 11. Component Evaluation Results Competence Improvement and Performance of Agencies in PoSWP Empowerment in West Sumbawa Regency

\begin{tabular}{|c|c|c|}
\hline $\begin{array}{c}\text { Aspect } \\
\text { Evaluated }\end{array}$ & Objective Comdition & Evaluation Result \\
\hline $\begin{array}{l}\text { I. Changes of competence } \\
\text { of management and } \\
\text { development of program } \\
\text { activities }\end{array}$ & $\begin{array}{l}\text { O Empowerment of Agencies has succeeded } \\
\text { in improving the competence and } \\
\text { performance in managing stimulant } \\
\text { program activities. } \\
\text { O Increased competence and performance of } \\
\text { the Renewal Agent, shown by the change } \\
\text { of mindset from the traditional to the } \\
\text { professional, so as to improve the ability } \\
\text { in the perspective effort, }\end{array}$ & $\begin{array}{l}\text { Already meet the criteria } \\
\text { Already includes all the } \\
\text { competencies needed to } \\
\text { support the performance of } \\
\text { the Renewal Agent.. }\end{array}$ \\
\hline $\begin{array}{l}\text { 2.Improvement } \\
\text { managerial } \\
\text { strategic skills }\end{array}$ & $\begin{array}{l}\text { O Management } 4 \text { and } \\
\text { administration of RPoMCE Pariri } \\
\text { activities, as well as development } \\
\text { strategies towards Productive } \\
\text { Economic Activities. } \\
\text { Has not succeeded in improving } \\
\text { initiative and entrepreneurial spirit } \\
\text { (interpenership) for the Agent of }\end{array}$ & $\begin{array}{l}\text { Have not met the } \\
\text { criteria } \\
\text { Not yet fully master what } \\
\text { and how the development } \\
\text { strategy of PEA. }\end{array}$ \\
\hline
\end{tabular}




\begin{tabular}{|c|c|c|}
\hline & $\begin{array}{l}\text { Change, so it can be an ineffective } \\
\text { condition. }\end{array}$ & \\
\hline $\begin{array}{l}\text {.Implementation of } \\
\text { competence in the } \\
\text { management of } \\
\text { program activities }\end{array}$ & $\begin{array}{l}\text { The implementation has not reached all } \\
\text { target groups that are the target of } \\
\text { empowerment of the Agent of Change. } \\
\text { Implementation of competence is still } \\
\text { less or not practiced in activities of } \\
\text { Agents because still weak initiative and } \\
\text { entrepreneurial spirit of the Agent of } \\
\text { Change itself in the effort of } \\
\text { developing Productive Economic } \\
\text { Activity }\end{array}$ & $\begin{array}{l}\text { Not yet meet the criteria } \\
\text { Not all competencies } \\
\text { have been applied in the } \\
\text { management and } \\
\text { development of RPoMCE } \\
\text { program activities. }\end{array}$ \\
\hline
\end{tabular}

The results of the evaluation indicate that the empowerment of PMKS community implemented in West Sumbawa Regency has succeeded in improving the competence and performance of Renewal Agent. However, such success has not reached all the Renewal Agents that are part of the Peliuk dealer group.

\subsection{Development of Productive Economic Empowerment and Impact on the Improvement of Community Welfare.}

Improving the welfare of the community is focused on assessing the impact of the empowerment of the Agent of Change on the enhancement of the contribution of the Production Economic Activity to the welfare of the community. In its development was introduced Creative Economy Activities, which will provide a side business opportunity for the beneficiary PoSWP community and has been successful. The success is certainly a realistic example that can be understood and shared for adoption by other participants.

Table 12. Evaluation Results Components of Productive Economic Empowerment Development and Impact on Community Welfare Improvement in West Sumbawa Regency

\begin{tabular}{|c|c|c|}
\hline $\begin{array}{c}\text { Aspect } \\
\text { Evaluated }\end{array}$ & Objective Conditions & Evaluation Results \\
\hline $\begin{array}{l}\text { 1. Benefits to the } \\
\text { development of } \\
\text { Productive Economic }\end{array}$ & $\begin{array}{l}\text { Empowerment Development encourages } \\
\text { the interest of the Agent of Change to } \\
\text { provide input in such a way that the } \\
\text { Productive Economic Activity is } \\
\text { responded by the Local Government } \\
\text { strengthened with the local regulation and } \\
\text { its implementation runs as expected. } \\
\text {. }\end{array}$ & $\begin{array}{l}\text { Already meet the criteria. } \\
\text { The products in the form of } \\
\text { Stimulant Activity } \\
\text { development are applied by } \\
\text { adjusting and enhancing the } \\
\text { roles, competencies, and } \\
\text { potential of the Agent of } \\
\text { Change. }\end{array}$ \\
\hline $\begin{array}{l}\text { 2. Empowerment that has } \\
\text { evolved productively } \\
\text { Productive Economic } \\
\text { Activity. }\end{array}$ & $\begin{array}{l}\text { The development of productive economic } \\
\text { activities must be in line with the } \\
\text { empowerment it self. Tasks and Roles of } \\
\text { Agent of Change done through; } \\
\text { Development of Productive Economic } \\
\text { Activity is confronted with the constraints } \\
\text { of the limited acceptance of the Poor to } \\
\text { understanding, understanding for the } \\
\text { development of the investment aspect. } \\
\text { Activities developed specifically for the } \\
\text { Stimulant Gotong Royong Activities. } \\
\text { And therefore Professionalization to } \\
\text { improve the competence and } \\
\text { professionalism of the Agent of Renewal, } \\
\text { immediately through the provision of } \\
\text { education and training. } \\
\text { Activities developed specifically for the } \\
\text { Stimulant Gotong Royong Activities. } \\
\text { And therefore Professionalization to } \\
\text { improve the competence and }\end{array}$ & $\begin{array}{l}\text { Simply Meets the criteria. } \\
\text { Focused developments are } \\
\text { appropriate to enhance the } \\
\text { roles, competencies, and } \\
\text { potential of Updating } \\
\text { Agencies. With } \\
\text { Empowerment will } \\
\text { encourage productivity. }\end{array}$ \\
\hline
\end{tabular}




\begin{tabular}{|c|c|c|}
\hline & $\begin{array}{l}\text { professionalism of the Agent of Renewal, } \\
\text { immediately through the provision of } \\
\text { education and training. } \\
\text { Strengthening the capacity to increase the } \\
\text { potential of the Agent of Change in the } \\
\text { development of the Productive Economic } \\
\text { Activity through the establishment and } \\
\text { fostering of the Agent of Change group } / \\
\text { organization. }\end{array}$ & \\
\hline $\begin{array}{l}\text { 3. Utilization of results } \\
\text { for the community in } \\
\text { the field of social } \\
\text { community. }\end{array}$ & $\begin{array}{l}\text { Program activities are generally direct } \\
\text { assistance, then developed towards interest } \\
\text { and interest with development efforts } \\
\text { especially the; Stimulant Fund } \\
\text { o Empowerment of self potential, will } \\
\text { encourage productivity } \\
\text { o Productivity of the poor by breaking the } \\
\text { minds of dwarfs, } \\
\text { o Utilization of real results \& interactive } \\
\text { social relationships of the community } \\
\text { o Empowerment \& contribution of } \\
\text { Productive Economic Activity to } \\
\text { community level of life } \\
\text { masyarakat }\end{array}$ & $\begin{array}{l}\text { Already meet the criteria. } \\
\text { The methods used are } \\
\text { appropriate to enhance the } \\
\text { role, competence, and potential } \\
\text { of the Agent of Change. } \\
\text { Empowerment not only } \\
\text { encourages the productivity of } \\
\text { the Agent of Change but has } \\
\text { driven the changing mindset } \\
\text { and productivity of society }\end{array}$ \\
\hline $\begin{array}{l}\text { 4. Community } \\
\text { Empowerment Level } \\
\text {. }\end{array}$ & $\begin{array}{l}\text { Implementation of the program and its } \\
\text { positive implications on the Community } \\
\text { Welfare Level; This PDPGR is the poor in } \\
\text { the sector; Micro, Agriculture, Livestock, } \\
\text { and Fishery \& Marine; } \\
\text { o Empowerment and change though slow } \\
\text { but sure, } \\
\text { o Being a solution in overcoming poverty } \\
\text { in the socio-economic structure of } \\
\text { society, } \\
\text { o Development and Enhancement of } \\
\text { Productive Economic Activities will } \\
\text { encourage increased community activity } \\
\text { and creativity } \\
\text { o Productive Economic Activity is strongly } \\
\text { correlated in Business Capital } \\
\text { Strengthening. }\end{array}$ & $\begin{array}{l}\text { Not fully meet the criteria } \\
\text { Understanding becomes the } \\
\text { focus of what transformation } \\
\text { and meaning of Development } \\
\text { Activities. And various efforts } \\
\text { and tricks are used accordingly } \\
\text { to enhance the role, } \\
\text { competence, and potential of } \\
\text { the Updating Agent. } \\
\text { With Empowerment will } \\
\text { encourage productivity. }\end{array}$ \\
\hline
\end{tabular}

The socialization of the guidelines and the various regulations became intent, to be properly understood. Professionalization is implemented through education in the form of guidance, counseling, training, and workshop activities. Group coaching is done through the formation of Association / Agent Forum in each of the adjacent Villages, and through meetings and coaching, facilitation, consultation and advocacy are also initiated by the association. The activities of the association are directed to establish partnerships and / or cooperation with related parties with the development of Agent of Change and development towards professionalism.

The results of the evaluation indicate that the empowerment of the Agent of Change has not provided optimal benefits to the development of productive economic activities of the poor.

\section{Conclusion}

Overall it has met the criteria, although for some factors, the indicator shows not yet fully meet the criteria. Some of the indicators used in this research are the target beneficiaries, community participation, and benefits received by the community. Based on the observations in the field and data processing obtained that 
First; for beneficiary target indicators, the most beneficiaries of these PoSWP are poor communities of the term Social Welfare Problems, in sectors; Micro, Agriculture, Livestock, and Fishery \& Marine. Second; Indicator of community participation, obtained category in good participation. Third; for the benefit indicator received, it was found that the benefits of the skills, knowledge, health, and income received by the village community were categorized in the moderate rise category. And as the conclusion, However, the Agent of Change through the Regional Program of Mutual Cooperation Empowerment, has been able to significantly reduce the poverty rate, especially the poor with the predicate of the People with Social Welfare Problems.

\section{Acknowledgement}

The authors greatly acknowledge the support from Jakarta State University, UNJ, for providing necessary resources to carry out this research work. The authors are also grateful to the anonymous reviewers and journal editorial board for their many insightful comments, which have significantly improved this article.

\section{References}

[1] Angela Baron \& Michael Armstrong.(2013). Human Capital Management;Achieving Added Value Through People, Edisi Indonesia, Alih Bahasa; Lilian Juwono. Jakarta: Ppm, Menteng Raya.

[2] Bozarth, J. (2009, January 17). Alternatives To Kirkpatrick [Weblog Post]. Retrieved From Http://Bozarthzone.Blogspot.Com/2009/01/Alternatives-To-Kirkpatrick.Html

[3] Brinkerhoff, R. O. (2009). The Success Case Method: Find Out Quickly What's Working And What's Not (2nd Ed.). San Francisco, Ca: Berrett-Koehler Publishers. Pdf Chapter 1 Except. AvailableFrom: Http://Www.Bkconnection.Com/Static/The_Success_Case_Method_Excerpt.Pdf

[4] Bupati Sumbawa Barat ; Regulation of Regional Number 3 of 2016 concerning; Regional Program of mutual cooperation Empowerment (PDPGR).

[5] Bupati Sumbawa Barat ; Regional Regulation Number 8 of 2016 concerning; Medium Term Plan (RPJMD) Year 2016-2021.

[6] Bupati Sumbawa Barat ; Regulation of Regional Number 19 of 2016 concerning; The PDPGR Guidelines for Planning, May 30, 2016.

[7] Castellano, William G. (2015). A New Framwork Of Employee Engagemen(Epe White Paper). New Jersey: Rutger School Of Management \& Labor Relations.

[8] Daniel L Stufflebeam, Chris L. S. Cornyn. (2014).Evaluation; Theory; Models And Application, Second Edition Jossey-Bass.A Wiley Brandsan Fransisco, Ca94104-4594 USA

[9] Daniel L. Stufflebeam. Cipp Evaluation Model Checklist ; The Cipp Evaluation Model Is A Comprehensive Framework For Guiding Evaluations Of Programs A Tool For Applying The Cipp Model To Assess Long-Term Enterprises. Intended For Use By Evaluators And Evaluation Clients/Stakeholders [Second Edition] March 17, 2007

[10] David Jeffee.Organization Theory,Tension And Change, Mc.Graw Hill International EditionSociology Series 2001 P. 20-41

[11] David L Goetsch, Stanley Davis See. Quality Management For Organizational Exellence; Introduction To Total Quality (C) 2014 Seven Edition. Pearson Education Limited, Edinburg Gate , Harlow Essex Cm 202je England

[12] Donald L.Kirkpatrick And James D,Kirkpatrick. Evaluation Training Programs,The Four Levels, $3^{\text {rd }}$ Edition Copyright (C) 2006, Berrett-Koehler Publishers Inc.235 Montgomery Street 650San Fransisco-California 94104-2916USA

[14] E Jane Davidson. (2005).Evaluation Metodology Basics;The Nuts And Bolts Of Sound Evaluation, Copyright (C) International Edition, By Sage Publication Inc.2455 Teller Road Thousand Oaks California USA - 91230

[15] Egon G. Guba And Yvonna S. Lincoln. Effective Evaluation;Improving The Usefulness Of Evaluation Research Through Responsive And Naturalistics Approaches, Copyright (C) 1981 Second Edition Jossey-Bass Inc. Publishers California Street, San Fransisco-California Ca94104 USA

[16] Elie Greisler And Nilmini Wickramasingh., Principles Of Knowledge Management; Theory, Practice, And Cases, Copyright (C) 2009,By M.E. Sharpe Inc.80 Busness Park Drive Armonk New York NY-USA 10504 
[17] Essy Irvianti, Evaluation Of New Entrepreneur (Wub) Program In Bandung City Using Cipp Model Journal Of Business And Management Vol. 6 No.1, 2017: 80-87 ,School Of Business And Management Institut Teknologi Bandung, Indonesia . Essy.Irvianti@Sbm-Itb.Ac.Id

[18] Evert Vedung ; Models Of Evaluation Vedung, Evert. (2000).Public Policy And Program Evaluation. New Brunswick, Nj: Transaction Pulisherbs.

[19] Farhad Analoui. (2007). Strategic Human Resources Management; International Development, Human Resources Management, Bradford For International Development. University Of BradfordThomson

[20] Gary Cokins, Performance Management ; Integrating Strategy, Execution, Methodologies, Risk And Analytics. $3^{\text {rd }}$ Edition Copyright (C) 2009, Published By John Willey And Sons Inc.HobokenNew Jersey USA

[21] Gary Dressler, Human Resources Management, Pearson Education Limited, Publishing As Prentice Hall Copyright (C) 2011 Edinburgh Gate,Harlow Essexcm20 2je, England.

[22] George A Steiner And Joh A Minner ;Management Policy And Strategy, Text Reading And Cases

[23] Gram, T. (2011). Comparison Of Kirkpatrick Based Models And The Success Case Method Https://Performancexdesign.Files.Wordpress.Com/2011/02/2011-02-23_2243. Png

[24] Greenhaus, Jeffrey H, Callanan, Gerard ; Encyclopedias Of Career Development- Vocational Guidance ;. A. Sage Publications, Inc. 2455 Teller Road ThoUSAnd Oaks, California 91320 EMail: Order@Sagepub.Com Hf5381.E5172006

[25] Guili Zhang, Nancy Zeller, Robin Griffith, Debbie Metcalf, Jennifer Williams, Christine Shea, And Katherine Misulis, Using The Context, Input, Process, And Product Evaluation Model (Cipp) As A Comprehensive Framework To Guide The Planning, Implementation, And Assessment Of ServiceLearning Programs (C) Journal Of Higher Education Outreach And Engagement, Volume 15, Number 4, P. 57, (2011)Copyright (C) 2011 By The University Of Georgia. All Rights Reserved. Issn 1534-6104

[26] Harvard Business Essentials, Time Management; Increase Your Personal Productivity And Effectiveness, Copyright 2005 Harvard Business School Publishing Corporation 60 Harvard Way, Boston Massachussetts-02163 USA

[27] Hatice Sancar Tokmak, H. Meltem Baturay, And Peter Fadde mersin University, Turkey, ipek University, Turkey, ${ }^{3}$ southern Illinois University Carbondale (Siuc), United States Applying The Context, Input, Process, Product Evaluation Model For Evaluation, Research, And Redesign Of An Online Master's Program.Home > Vol 14, No 3 (2013) >Sancar Tokmakjuly - 2013

[28] Helen N. Rothberg And G Scott Ericson, From Knowledge To Intellegence ; Creating Competitive Advantage, Copyright (C) 2005 Elsevier Butterworthheinemann, 200 Wheeler Road Burlington Ma 01803, USA

[29] Michael A.Hitt, R.Duane Ireland \& Robert E. Hoskisson. Concepts \& Cases, $9^{\text {th }}$ Edition Copyright $\odot$ 2015 Strategic Management, Competitiveness \& Globalization. Cengage Learning, 200 First Stamford Place, 4floor, Stamford,Ct 06902 USA

[30] Ian Palmer, Richard Dunford, Gib Akin, Managing Organization Change ; A Multiple Perspectives Approach, $2^{\text {nd }}$ Edition Copyright $(2009$ International Edition Mc.Graw Hill Companies Inc. 1221 Avenue Of The Americas, New York, Ny - USA 10020

[31] I Made Sundayana, Director/Lecture Of Health Education, Buleleng School Of Health Bali, Indonesia ; Implementation Of Computer Assisted Cipp Model For Evaluation Program Of Hiv/Aids Ountermeasures In Bali (Ijarai) International Journal Of Advanced Research In Artificial Intelligence, Vol. 4, No.11, 2015 27. www.Ijarai.Thesai.Org

[32] Jackson, SUSAn E., Michael A. Hitt, \& Angelo S. Denisi. ... Managing Knowledge For Sustained Competitive Advantage. Forward

[33] James C. Mcdavid, Laura R.L.Hawthorn, Program Evaluation \& Performance Measurement; An Introduction To Practice, Copyright (C) 2006, By Sage Publication Inc.2455 Teller RoadthoUSAnd Oaks California USA - 91230

[34] Jeremy Hope,Steve Player, Beyond Performance Management ; Why, When And How To Use 40 Tools And Best Practices For Superior Business Performance, Copyright (C) 2012 Harvard Business Review Press USA 
[35] Jati Aurum Asfaroha, Dadan Rosanaa, Supahara. Development Of Cipp Model Of Evaluation Instrument On The Implementation Of Project Assessment In Science Learning, International Journal Of Environmental \& Science Education 2017, Vol. 12, No. 9, 1999-2010 Yogyakarta State University, Yogyakarta, Indonesia

[36] Jati Aurum Asfaroha, Dadan Rosanaa, Supahara ;Development Of Cipp Model Of Evaluation Instrument On The Implementation Of Project Assessment In Science Learning, International Journal Of Environmental \& Science Education 2017, Vol. 12, No. 9, 1999-2010 Yogyakarta State University, Yogyakarta, Indonesia

[37] John H Piere Ii And Richard B. Robinson Jr; Strategic Management. Formulation, Implementation And Control. Jilid I\&Ii 1997, Alih Bahasa Ir.Agus Maulana,MsmBinarupa Aksara, Jakarta

[38] Jody L.Fitzpatrick, Christina Christie, Melvin M. Mark, 2009, Evaluation In Action ; Interview With Expert Evaluators, Copyright (C) International Edition, By Sage Publication Inc.2455 Teller RoadthoUSAnd Oaks California USA - 91230

[39] Jody L.Fitzpatrick, James R. Sander,Blame R. Worthen, 2012, Program Evaluation ; Alternatives Approaches And Practical Guidelines, International Edition, Fourth Edition, Pearson Education Inc. New Jersey USA

[40] John M. Ivancevich And Robert Konopaske ;Human Resources Management ;International Edition Copyright (C) Twelfth Edition 2013, Published By Mc.Graw-Hill/Irwin Business Unit Of The Mc.Graw-Hill Companies Inc. 1221 Avenue New York Ny USA 10020

[41] John Maxwell Owen. Program Evaluation; Forms And Approach, $3^{\text {rd }}$ Edition, Copyright (C) 2006, Allen \& Unwin 83 A;Expander Street Crows Nest Nsw 2065 Australia

[42] John W. Creswell. Research Design; Pendekatan Kualitatif, Kuantitatif Dan Mixed, Edisi Ketiga, Penerjemah. Achmad Fawaid. Penerbit Pustaka Pelajar Celeban Timur Uh. Iii/548 Yogyakarta

[43] John W. Creswell, Qualitative Inquary \& Researh Design ; Choosing Among Five Approaches. $2^{\text {nd }}$ Edition, Copyright (C) 2007. Saga Publication Inc. 2455, Teller Road ThoUSAnd Oaks, California 91230

[44] Kathryn E. Newcomer, Harry P.Hatry, Joseph S. Wholey ; Handbook Of Practical Program Evaluation, Copyright (C) 2015 Fourth Edition Jossey-Bass A Wiley Imprint. Published By John Wiley \& Sons Inc.Hoboken New Jersey 07030 USA

[45] Kirkpatrick Partners. (2015). The Kirkpatrick Model. Retrieved From Http://Www.Kirkpatrickpartners.Com/Ourphilosophy/Thekirkpatrickmodel/Tabid/302/Default. Aspx

[46] Kurt Schoch, Edd ; Smile Sheets Are Not Enough: An Effective, Systematic Approach To Program And Educational Evaluation Using Cipp Indiana Evaluation Association October 20, 2017. Performance Improvement Consulting, Llc, Www.Kwschochconsulting.Com, Kurt@Kwschochconsulting.Com. 317-455-5725 Indiana Evaluation Association - October 20, 2017

[47] L.Cronbach.Essential Of Psycological Testing, Edisi Ketiga. New York: Harper \& Row Marvin C. Atkin .(2013).Evaluation Roots; A Wider Perspective Of Theorists' Views And Influences, Copyright (C) Second Edition. USA: Sage Publication Inc.

[48] Michael Armstrong. (2006).A Hand Book Of Human Resources Management Practice, $10^{\text {th }}$ Edition Great Britain: Cambridge University Press.

[49] Michael Armstrong. (2009).Performance Management; Key Strategies And Practical Guidelines. $3^{\text {rd }}$ Edition. New Jersey USA: John Willey And Sons Inc.Hoboken

[50] Michael Quinn Patton. (2011).Develovment Evaluation;ApplyingComplexity Cocepts To Entrance Innovation And Use. New York: The Guilford Publication Inc., Spring Street.

[51] Michael Quinn Patton. (2011).Qualitative Reasearch \& Evaluation Methods. Oaks California USA: Sage Publication Inc.

[52] Michael R. Carrell \& Christina Heavrin. (2013). Labor Relations And Collective Bergaining; Private And Public Sectors, Tenth Edition. USA: Pearson Education.Inc. Publishing As Prentice Hall

[53] Mike Green. (2007).Change Management Masterclass;A Step By Step To Successful Change, By Kogan Page Limited 525 South $4^{\text {th }}$ Street \# 241 Philadelphia Pa-USA 19147

[54] Mondy \& Noe (Mondy, R. Wayne \& Noe, Robert M. (2005).Human Resources Managemen.USA: Prentice Hall, Pearson Education. 
[55] Nunes, Miquel Baptista, Annansingh, Fenio, Eaglestone, Barry, \& Wakefield, Richard, Knowledge Management Issues In Knowledge-Intensive Smes, Journal Of Documentation, 2006; 62. Uk.

[56] Pasher, Edna \& Tuvya Ronen. (2011). The Complete Guide To Knowledge Management;A Strategic Plan To Leverage Your Company's Intellectual Capital. New Jersey : John Wiley \& Sons Inc.

[57] Pemkab. Sumbawa Bawa Barat, Suara Ktc, Buletin, Edisi 2 Tahun 2016, Http://Sumbawabaratkab.Go.Id

[58] Richard L. Hughes, Robert C.Ginnett And Gordy J. Curphy. (2012). Leadership ; Enchancing The Lessons Of Experience. New York: Mc. Graw-Hill Irwin Companies Inc.

[59] Robinson, Dilys Et.Al. (2004). The Drivers Of Employee Engagement (Report 408). Brighton: Institute Employment Studies.

[60] Roger Chevallier .A Manager's.Guide To Improve Workplace Performance;Identifying Problems, Finding Solutions And Evaluating Results, Amacom, A Division Of American Management Association, 1601 Broadway New York Ny10019 USA

[61] Robert Bacal . (2012). Manager's Guide To Performance Management, Second Edition. New York: Mcgraw Hill.

[62] R. Wayne Mondy, Joseph J. Martocchio. (2016). Human Resources Management, Fourteenth Edition. Pearson Education Limited. England: Edinburg Gate.

[63] Rodgers, R. "A Student Affairs Application Of The Cipp Evaluation Model", In Kuh, G. 1979, Evaluation In Student Affairs) Using The Context, Input, Process, And Product Evaluation Model (Cipp Model) Of Daniel L. Stufflebeam Http://Www.Hettler.Com/Direct/Assess/Using\%20the\%20context.Htm

[64] Shelda Debowski. (2006).Knowledge Management ; First Edition. John Wiley And Sons Australia, Ltd.

[65] Stanley Oliver, Accountant's Guide To Management Techniques, Gowe Free Limited, Epping, Esssex Great Britain; 1975

[66] Stufflebeam, D. L. (March, 2007). Cipp Model Evaluation Checklist, 2nd Edition. Http://Www.Wmich.Edu/Evaluation/Checklists

[67] Susan E. Jackson, Michael A.Hitt, Angelo S.Denisi. (2003). Managing Knowledge For Sustained Competitive Advantage; Designing Strategies For Effective Human Resources Management,First Edition By. John Wiley \& Sons Inc. USA: Jossey-Bass.A Wiley Imprint.

[68] Sugiyono. (2005).Memahami Penelitian Kualitatif; Dilengkapi Contoh Proposal Dan Laporan Peneltian, Cetakan Kesatu. Bandung: CV. Alfabeta.

[69] Timred Fokusmedia 2004, Undang-Undang Otonomi Daerah, Penerbit Fokus Media, Jalan Melati Mekar No.2 Komplek Panghegar Bandung 40613

[70] Teh, I. (2015, March 12). Cipp Evaluation Model [Weblog Post]. Retrieved From Http://IvantehRunningman.Blogspot.Com/2015/03/Cipp-Evaluation-Model.Html

[71] Utsman ; Evaluasi Program Pembangunan Masyarakat Dengan Model Cipp, Filename: Evaluasi Program Pembangunan Masyarakat Desa I_4de4b4.Docx Ut_Unnes@Yahoo.Com

[72] UU Desa, Transmigrasi Dan Daerah Tertinggal Pasal 83 UU Desa Nomor. 6 Tahun 2014 Pemberdayaan Masyarakat; Konsultan-Pemberdayaa-Blogspot.Co.Id/2014

[73] UU Desa, Transmigrasi Dan Daerah Tertinggal Pasal 83 UU Desa Nomor. 4 Tahun 2017 Https://Www.Jogloabang.Com/Peraturan-Menteri-Desa-Nomor-4-Tahun-2017

[74] Willian Dunn. (2008). Public Policy Analysis;An Introduction. New Jersey-USA: Pearson Education Inc. 